\title{
Retraction Note: Risk factors, clinical presentations and predictors of stroke among adult patients admitted to stroke unit of Jimma university medical center, south west Ethiopia: prospective observational study
}

\author{
Ginenus Fekadu ${ }^{1 *}$, Legese Chelkeba ${ }^{2}$ and Ayantu Kebede ${ }^{3}$
}

Retraction Note: BMC Neurol (2019) 19:183 https://doi.org/10.1186/s12883-019-1412-5

The Editor and Publisher have retracted this article [1]. This article was published as the result of a technical error which resulted in two versions $[1,2]$ of the same article being published. [2] is the final version of the article. Springer Nature apologises to the authors and to readers for the inconvenience caused. All authors agree with this retraction.

\footnotetext{
Author details

${ }^{1}$ Clinical Pharmacy Unit, Department of Pharmacy, Institute of Health Sciences, Wollega University, P.O Box 395, Nekemte, Ethiopia. ${ }^{2}$ School of Pharmacy, Institute of Health, Jimma University, Jimma, Ethiopia.

${ }^{3}$ Department of Epidemiology, Institute of Health, Jimma University, Jimma, Ethiopia
}

Published online: 17 December 2019

\section{References}

1. Fekadu G, Chelkeba L, Kebede A. Risk factors, clinical presentations and predictors of stroke among adult patients admitted to stroke unit of Jimma university medical center, south west Ethiopia: prospective observational study. BMC Neurol. 2019:19:183. https://doi.org/10.1186/s12883-019-1412-5.

2. Fekadu G, Chelkeba L, Kebede A. Risk factors, clinical presentations and predictors of stroke among adult patients admitted to stroke unit of Jimma university medical center, south west Ethiopia: prospective observational study. BMC Neurol. 2019;19:187. https://doi.org/10.1186/s12883-019-1409-0.

\footnotetext{
* Correspondence: take828pharm@gmail.com; ginenus@wollegauniversity.edu.et

The original article can be found online at https://doi.org/10.1186/s12883019-1412-5

${ }^{1}$ Clinical Pharmacy Unit, Department of Pharmacy, Institute of Health

Sciences, Wollega University, P.O Box 395, Nekemte, Ethiopia

Full list of author information is available at the end of the article
}

(c) The Author(s). 2019 Open Access This article is distributed under the terms of the Creative Commons Attribution 4.0 International License (http://creativecommons.org/licenses/by/4.0/), which permits unrestricted use, distribution, and reproduction in any medium, provided you give appropriate credit to the original author(s) and the source, provide a link to the Creative Commons license, and indicate if changes were made. The Creative Commons Public Domain Dedication waiver (http://creativecommons.org/publicdomain/zero/1.0/) applies to the data made available in this article, unless otherwise stated. 